\title{
Biogeographic relationships among deep-sea hydrothermal vent faunas at global scale
}

\author{
C. Bachraty ${ }^{a,}{ }^{*}$, P. Legendre ${ }^{a}$ and D. Desbruyères ${ }^{b}$
}

\footnotetext{
a Département de sciences biologiques, Université de Montréal, C.P. 6128, succursale Centre-ville, Montréal, Québec, Canada H3C 3J7

${ }^{\mathrm{b}}$ Département Études des écosystèmes profonds, Ifremer, Centre de Brest, 29280 Plouzané, France
}

*: Corresponding author : Charleyne Bachraty, phone: (514) 343-7591; fax: (514) 343-2293, email address : Charleyne.Bachraty@umontreal.ca

\begin{tabular}{l}
$\begin{array}{l}\text { Email adresses } \\
\text { ddesbruy@ifremer.fr }\end{array}$ \\
\hline
\end{tabular}

\begin{abstract}
:
The discovery of deep-sea hydrothermal vent fauna, kilometres deep in the oceans, is a great achievement of 20th-century marine biology. The deep-sea hydrothermal food web does not directly depend on the sun's energy. Vent communities rely primarily on trophic associations between chemoautotrophic bacteria and consumers. A small number of endemic taxa are adapted to the inhospitable vent environments that are distributed along ridge crests. Where these vent communities originated and how they dispersed are among the important questions ecologists must answer. Here, by statistical analysis of the most comprehensive database ever assembled about deep-sea hydrothermal fauna, we delineate six major hydrothermal provinces in the world ocean and identify seven possible dispersal pathways between adjacent provinces. Our model suggests that the EastPacific Rise may have played a pivotal role as a centre of dispersal for the hydrothermal fauna. Our data-driven conclusion will have to be tested by phylogenetic studies and completed by surveys of less-explored fields.
\end{abstract}

Keywords: Biogeographic provinces; Centre of dispersal; Coefficients of dispersal direction; Deepsea hydrothermal vent communities; Minimum spanning tree; Multivariate regression tree 


\section{Introduction}

Discovered in 1977 at 2500 meter depth on the Galapagos Spreading Centre, deep-sea hydrothermal vent communities have been located and studied over different geological and dynamic environments: fast to slow-spreading mid-oceanic ridges, back-arc basins, volcanic arcs, and active seamounts. On ridge crests, vent habitats are distributed linearly as small mixing cells between hot fluids and seawater, occurring at irregular intervals (Tunnicliffe et al. 1998). The associated vent fauna is primarily composed of a small set of large organisms relying on symbioses with chemoautotrophic bacteria, able to withstand extreme conditions and persist in a discontinuous and ephemeral environment. A larger set of accompanying smaller species relying on heterotrophy (deposit or suspension feeders, carnivores or scavengers) are also conspicuous members of this fauna. A large majority (82\% according to McArthur and Tunnicliffe, 1998) are unrecorded from other marine settings and thus have been described as specialized or "endemic" to these toxic, unstable and patchy environments. This endemicity at the species level has been debated since the discovery of hydrothermal vents. The repopulation of deep-sea vents from shallower refugia after deep-water, has been considered after deep-water anoxic/dysoxic events during the late Cretaceous and early Tertiary (Jacobs and Lindberg, 1998; Chevaldonné et al., 2002). If that extinction event happened, seep communities should have been similarly affected. However, recent studies suggest that the end-Cretaceous extinction event, and the earlier anoxic/dysoxic events, had no significant influence on deep-sea vent and seep taxa (Kiel and Little, 2006).

The basic pattern of faunal distribution to emerge is an inverse relationship between faunal similarity and distance separating vent fields (Hessler and Lonsdale, 1991). Discontinuities of the ridges, as well as hydrological barriers, limit the along-axis dispersal and favour allopatric speciation. At the global scale, biogeographic factors (physical barriers and corridors) that contribute to the isolation of vent faunas on different ridge segments or complexes may yield different, separately evolved sets of species filling the same niches (Tunnicliffe et al., 1996; Tunnicliffe et al., 1998) and cause isolation of species groups by the process of vicariance.

Biogeography deals with the existence of different faunistic and floristic patterns, at different spatial and time scales, in the terrestrial and marine environments. Biogeography seeks to identify these patterns as well as the forces that shaped present-day distributions of taxa or communities, at different taxonomic levels (Tunnicliffe et al., 1998). Distribution patterns are described by a set of biogeographic "provinces", which represent one of the oldest concepts in biogeography (Nelson and Platnick, 1981). The biogeographic provinces are intended to describe the results of broad scale to fine-scale processes such as speciation, extinction, dispersal, and species interactions, that can generate and maintain taxonomic diversity (Briggs, 1974). The broad-scale processes essentially refer to movements of tectonic plates, sea-level changes, and the formation of barriers to dispersal such as fractures (Hedges et al., 1996); the small-scale processes act on the composition, richness, diversity, abundance, and recruitment of the communities (Rosenzweig, 1995).

Biogeographic studies of vent communities are of particular interest because of the characteristics of these ecosystems. (1) linear and patchy distributions along spreading centres can cause isolation of a group of species. (2) hydrothermal species are specific to their environment (Little and Vrijenhoek, 2003). (3) species with a long history of endemicity have probably diversified within the vent and seep habitats (Van Dover et al., 2002). Molecular clocks show that presently dominant groups of organisms in vents and seeps are relatively young $(\leq 126 \mathrm{Ma}$, diversification in the late Cretaceous and Cenozoic; Hurtado, 2002). Their appearance can be correlated with the last phases of the break-up of Pangaea. These recent groups have probably been derived from ancestors living in other deep-sea (e.g. seeps) and shallow-water ancestors (Black et al., 1997).

In early studies of hydrothermal vent biogeography, the criteria used to define provinces were essentially interpretive, based on faunal composition at the specific or supra-specific levels, the rate of endemicity, and evidence for vicariance and historical dispersal. The first biogeographic model was proposed by Tunnicliffe (1997) on the basis of the faunal composition and historic geological events. It contained seven provinces (Atlantic, Japan-Mariana basins, West-Pacific, Northeast 
Pacific, Northern East Pacific Rise, Galapagos and Southern East Pacific Rise). A model with four provinces (East-Pacific, North-Pacific, West-Pacific and Mid-Atlantic Ridge) was constructed by Mironov (1998), who examined distributions of both hydrothermal taxa and non-hydrothermal taxa (those living near vents but not depending on hydrothermal circulation) because he considered that the biogeographic organization of the two faunas depended on the same factors, namely tectonic history, dynamic ridges and environmental conditions. In 1998, Tunnicliffe published a compilation of the taxonomic and environmental characteristics of her new model, which comprised five provinces (Northeast Pacific, West-Pacific, Mid-Atlantic Ridge, Southern East Pacific Rise, Southwest Pacific from the Fiji basin). For the first time, a comparison with cold seep communities was made and the joint influence of dispersion and vicariance processes on the distribution of communities among the hydrothermal provinces was evaluated. A biogeographic model of vent faunas with six provinces was derived by Van Dover et al., 2002 mainly from correlations between these provinces and the geographical locations of the ocean basins, and from the degrees of isolation along the mid-ocean ridge system, the bathymetry and vicariance events. The latter include the fact that the East Pacific Rise and the northeast Pacific ridge system once formed a continuous plate boundary that was split -28 $\mathrm{Ma}$ ago by the overriding North American plate. Finally, in addition to the already described provinces (East Pacific Rise, Northeast Pacific, Mid-Atlantic Ridge, Western Pacific, Indian Ocean), the nine-province model of Tyler and Young (2003) considers the little-explored zones (Arctic, East Scotia Ridge) as "potential" provinces. It also recognizes the western Pacific sites of the back-arc basins and the site of Loihi as distinct provinces (Fig. 1; Table 2).

Statistical methods were used in previous studies mainly to compare vent communities between segments on the same ridge (Gebruk et al., 1997; Van Dover, 2002; Tsurumi and Tunnicliffe, 2003). They were rarely applied to presence-absence of taxa in all vent fields because the faunal data available were insufficient to be used in statistical or biological/ecological studies (Van Dover, 1995; Jollivet, 1996; Gebruk et al., 1997; Tsurumi and Tunnicliffe, 2003). The first global study of vents that involved multivariate analyses was a comparison of diversity study between the three major ridge systems (East-Pacific Rise, Atlantic ridge and Western ridges; Jollivet, 1996). The aim of that paper was not to describe new provinces but to analyze the characteristics of the provinces proposed by Tunnicliffe.

Our approach has benefited from a recent review of hydrothermal vent taxonomy based on the best direct information available from morphological taxonomy conducted during the past 30 years on 63 hydrothermal vent fields (Desbruyères et al., 2006). Advanced statistical methods were applied to this database to answer biogeographic questions about the broad-scale structure and dispersal of the vent fauna.

This study has two objectives: first, to propose and validate the clustering of vent fields into biogeographic provinces; second, to infer the direction of species dispersal between these provinces using dispersal models. The analyses involved three statistical steps: 1) clustering the hydrothermal fields by Multivariate Regression Tree (MRT) analysis; 2) calculation of faunal coefficients of dispersal direction ( $D D)$ among the groups (provinces) obtained from the previous step; 3 ) computation of a minimum spanning tree among these same groups (provinces).

\section{Material and methods}

The data were assembled from a recent compilation (Desbruyères et al., 2006), completed by studying the literature, databases on the World Wide Web (ChEss: http://www.noc.soton.ac.uk/chess/database/, NOAA: http://www.pmel.noaa.gov/, NeMO: http://www.pmel.noaa.gov/vents/nemo/) and by contacting researchers. A database for species and one for genera were constructed for 63 hydrothermal fields. They give the presence (coded 1) or absence (coded 0) of 592 species and 332 genera in each field (Fig. 1; Tables 1 and 2). To make the data amenable to least-squares analyses such as MRT, species data were subjected to a Hellinger 
transformation (Legendre and Gallagher, 2001), which consists of dividing each value by the row (field) sum and taking the square root of the result.

The Multivariate Regression Tree (MRT; De'ath, 2002) is a divisive clustering method for a multivariate response data table $\mathbf{Y}$ (the transformed data tables), which bases its binary divisions on external explanatory variables $\mathbf{X}$ that act as constraints on the formation of the groups. At each step, a partition is chosen, along the values of one of the explanatory variables $\mathbf{X}$, that maximizes the difference, for the response data $\mathbf{Y}$, between the two groups formed. The $R^{2}$, or equivalently the among-group sum-of-squares, is maximized at each division step. After the first partition, new partitions are identified in the two groups independently, in a hierarchical way. Trees can be compared using the number of groups and the overall fit measured by the R-square or its complement the relative error. Trees can be better evaluated and compared using their crossvalidation error which estimates predictive power. The tree with the smallest cross-validation error is often presented, but a tree with a different number of groups may also be retained when it corresponds better to the research objective.

MRT was used to obtain groups of fields that were similar in faunal composition and neighbours in space, thus delineating biogeographic provinces. Latitude and longitude were used to impose a constraint of spatial contiguity to the tree. Consequently, the tree will display groups of fields that are adjacent to each other in the world's oceans; these groups will form our hypothesis of biogeographic provinces. The tree was computed using the 'mvpart' library (De'ath, 2006) in the R statistical language ( $R$ Development Core Team, 2006) and redrawn along a scale of increasing values of the global $R^{2}$ statistic for the partitions obtained.

Coefficients of dispersal direction (DD coefficients; Legendre and Legendre, 1984; Legendre and Legendre, 1998) were computed to measure the flow of taxa that may have dispersed, in the past, from regions with high to low taxonomic richness (assumption 4 below), as witnessed by present-day richness gradients, assuming that past dispersal of communities has left traces in present-day distributions (assumption 3). The associated test of significance (below) gives statistical support to the empirically-discovered hypotheses of fluxes. We computed the coefficients at the genus level because we were looking for similarities in faunal composition between adjacent provinces that may have been produced by dispersal of organisms before the differentiation of some present-day species. Two types of coefficients were computed: $D D_{1}=[a /(a+b+c)] \times[(b-c) /(a+b+c)]$ and $D D_{2}=[2 a /(2 a+b+c)] \times[(b-c) /(a+b+c)] ; a$ is the number of taxa common to the two provinces considered, $b$ is the number of taxa exclusive to the first province, and $c$ to the second province. The first portion of each coefficient measures the similarity between regions (Jaccard index in $D D_{1}$, Sørensen index in $D D_{2}$ ) while the second portion measures the asymmetry in taxonomic composition. For each $D D$ coefficient, a McNemar test of asymmetry between the quantities $b$ and $c$ was computed; the Holm (1979) correction was applied to the significance level $\alpha$ to control for type I error caused by multiple testing. The significant coefficient values indicate significant asymmetry in taxonomic richness and support the hypothesis of a flux between adjacent provinces; the sign of a significant coefficient, given by the quantity $(b-c)$, indicates the direction of taxonomic flux; and the $D D$ value, which reacts to both the similarity and the asymmetry between provinces, estimates flow intensity. If data are missing for some taxa or there are identification errors, or differences in nomenclature among provinces, the $D D$ analysis results can be blurred; it is, however, quite unlikely that a false significant pattern will emerge from these errors. The results (Fig. 1) will thus be judged by the coherence of the overall pattern that will emerge. The coefficients were computed using the function 'bgdispersal' available in the 'vegan' R-language library (Oksanen et al., 2008). It provides $D D_{1}, D D_{2}, a, b$, and $c$ matrices, McNemar chi-square statistics for the tests of asymmetry, and their associated probabilities.

Interpretation of the $D D$ coefficients rests on four assumptions that may or may not be true for system under study. (1) taxa can only disperse between adjacent provinces; considering the past and present connections among oceans, among the 15 pairs of provinces, four were not adjacent and were not studied: Northwest Pacific $\leftrightarrow$ Southern East Pacific Rise, Northeast Pacific $\leftrightarrow$ Southern East Pacific Rise, Southern East Pacific Rise $\leftrightarrow$ Mid-Atlantic Ridge, and Southwest Pacific 
$\leftrightarrow$ Mid-Atlantic Ridge. (2) dispersal by active or passive migration is a likely mechanism among fields in each province and between adjacent provinces. (3) past dispersal has left traces in present-day distributions. Indeed, if no indication of taxa dispersal remains in present-day distributions, the coefficients cannot detect it; that is the basis for all historical research. (4) dispersal comes from provinces of high to low taxonomic diversity. This statement assumes that, because of historical (e.g. older provinces) or chance reasons, more taxa may have originated in some provinces than in others. If this fairly weak assumption is correct, then more taxa should have dispersed from provinces with high diversity to provinces with low diversity than the opposite. We entertained this hypothesis to find what picture of historical dispersal it led to for the deep-sea hydrothermal settings. Statement 4 also assumes that taxonomic richness in the pairs of regions that are compared is known with about the same degree of precision. That assumption is probably not true for some of the pairs of regions that we compared.

Assumption 4 may seem too constraining given the uncertainties of our knowledge about hydrothermal fauna because richness asymmetry may reflect in part an asymmetry in sampling intensity. An analysis of Jaccard $(a / a+b+c)$ and Sørensen $(2 a / 2 a+b+c)$ similarity matrices, which form the first portion of the $D D_{1}$ and $D D_{2}$ coefficients respectively, was also undertaken to provide an answer based on strict faunal similarity, without any use of the asymmetry of taxonomic diversity between provinces. From the similarity matrices, a minimum spanning tree (MST, described for example in Legendre and Legendre 1998, section 8.2) was computed, linking pairs of adjacent provinces. No test of significance is attached to similarity coefficients.

\section{Results}

The hydrothermal fields of the World's oceans were divided into biogeographic provinces by using MRT analysis of species-level faunal composition, with the latitude and longitude coordinates of the fields as constraints. A 6-province statistical model (Figs. 1 and 2) was retained because it offered sufficient resolution, given our data (63 fields in total), while being close to the model that had the lowest cross-validation error. That model explained $23.3 \%$ of the among-field variation. The statistical model delineates the following provinces: \#1 Northwest Pacific (Izu-Ogasawara arc, Okinawa Trough, Okinawa Arc, Japan ridge), \#2 Southwest Pacific (Mariana, Manus, North-Fiji and Lau back-arc basins, Kermadec arc, Tabar-Feni Volcanic Fore Arc, Intraplate Seamount, Central Indian Ridge), \#3 Northeast Pacific (Juan de Fuca, Explorer, Gorda ridges), \#4 Northern East Pacific Rise (NEPR), \#5 Southern East Pacific Rise (SEPR), Pacific-Antarctic ridge (one field only), and \#6 Northern Mid-Atlantic Ridge (MAR). Given the considerations outlined in the Introduction, we can consider these clusters as biogeographic provinces, with the understanding that these preliminary provinces may be split in the future when more vent fields have been explored.

$D D$ coefficients were used to identify community fluxes between adjacent provinces. Six significant fluxes (Holm-corrected probabilities $\leq 0.05$ ) were evidenced by $D D$ computations (Fig. 1). Five arrows originated in the Northern East Pacific Rise (NEPR), pointing towards the Northeast Pacific (NE), the Northwest Pacific (NW), the Southwest Pacific (SW), the Southern East Pacific Rise (SEPR), and the Northern Mid-Atlantic Ridge (MAR). The sixth arrow went from the Southwest Pacific (SW) to the Northeast Pacific (NE).

Fig. 3 (full lines) presents the minimum spanning tree computed among geographically adjacent regions. The Sørensen coefficient values are also indicated along the tree edges of the tree. The Jaccard coefficient produced the same minimum spanning tree, with of course different similarity values on the branches. The trees computed for the species database using the Jaccard and Sørensen indices had the exact same topology, but with different similarity values on the branches. 
The aims of this study were to develop a biogeographic model from a recent update of taxonomic and community composition information and to formulate preliminary explanations for it. The vicariance events that have probably influenced the distribution of the biogeographic provinces are relatively well known (Tunnicliffe et al., 1998). Nevertheless, the ephemeral character of vents and the potential dispersal capacity of larvae (Tyler and Young, 1999) suggest a role for dispersal processes on the distribution of vent taxa.

Our model presents six biogeographic provinces and seven possible dispersal pathways (Fig. 3). It also suggests that the East-Pacific Rise (NEPR and SEPR) may have played a pivotal role as a centre of dispersal for the hydrothermal faunas. Concerning the provinces, a biogeographic model of vent fauna with 6 provinces had already been suggested (Van Dover et al., 2002; see Introduction) but the criteria considered for the definition of the provinces were different. Consequently, the model was different too: Northeast Pacific, Northwest Pacific, East Pacific Rise, Indian Ocean, Azores and MAR. Our model differs in some additional important respects from other models proposed in the literature (Tunnicliffe, 1997; Mironov et al., 1998; Tunnicliffe, 1998; Tyler and Young, 2003). (1) The Southern EPR is defined as a separate province not combined with the Northern EPR. (2) The Northeast Pacific seems to be more closely linked to NEPR than to the NW or SW Pacific (see $D D$ and Sørensen coefficients in Fig. 3). (3) The Indian Ocean is combined with the SW Pacific, whereas the Azores fields are not separated from the other Atlantic fields.

Four dispersal pathways between the NEPR and the other provinces highlighted in our study have been discussed in the literature. 1) From the NEPR to the MAR. Because of the higher diversity and greater age of the Pacific Ocean, the fauna of the MAR fields include a subset of the Pacific fauna (Van Dover, 1995). Dispersal pathways have been assumed between the Pacific and North Atlantic Oceans via the Panama Isthmus (Van Dover, 2000) although no direct ridge connections have existed between the Pacific and Atlantic ridges. Exchanges may have taken place through such environments as cold seeps, where reducing hydrocarbon-rich fluid seepage occurs and chemosynthetic organisms are found, as well as food-falls such as sunken wood and vertebrate carcasses. They may also have occurred by dispersal of epipelagic or bathypelagic larvae. This deep-sea corridor stayed open until the complete closure of the Panama Isthmus $\sim 3 \mathrm{Ma}$ ago. The vanished Caribbean ridges and connections to the Eastern Pacific subduction trenches could explain the subset of Pacific species found in the Atlantic faunas (Van Dover, 1995). The now vanished Tethys Sea, between Eurasia and Africa, could have served as a direct conduit for dispersal of vent species from the Pacific to the North Atlantic about 100 Ma ago (Gebruk et al., 1997; Jollivet et al., 1998; Van Dover, 2000). Genera common to the Mid-Atlantic and Western Pacific fields suggests that the South-West Indian Ocean Ridge served as a conduit for contemporaneous dispersal between these regions through the South Atlantic (Hessler and Lonsdale, 1991). Whereas the connection between the South Atlantic and Indian Ocean ridges could allow present faunal exchanges, the Indian Ocean vent fauna is more similar to the Western Pacific than to the North Atlantic vent fauna (Van Dover et al., 2001). In our study, the Atlantic to Indian Ocean connection was not tested because of the paucity of data for the Indian Ocean (only 14 genera have been identified from the two vent fields explored) and the fact that no faunal composition data are presently available from South Atlantic vents, despite the recent discovery and exploration of active vent fields between $4^{\circ}$ and $10^{\circ} \mathrm{S}$ (German et al., in press).

2) From the NEPR to the western Pacific. Some $43 \mathrm{Ma}$ ago, the Kula Ridge, now subducted beneath Alaska, provided a direct link between the NEPR and the western Pacific basins (Hessler and Lonsdale, 1991). The ages of hydrothermal higher taxa (families and genera) are not in conflict with these geological events because most of them had already appeared before the subduction of the Kula Ridge (Tunnicliffe et al., 1996). Based on faunal similarity alone, the Sørensen coefficients suggest a link from the SEPR to the SW and on to NW, whereas the $D D$ analysis, which uses the asymmetry of faunal composition as additional information, suggests direct links from the NEPR to the SW and NW. These results are not contradictory; the fairly high similarity between the SEPR and 
the SW may result from faunal exchanges between the three regions the NEPR, the SEPR, and the SW. Similarly, the fairly high similarity between the SW and the NW, which also corresponds to a significant $D D$ arrow, may result from faunal exchanges from the NEPR to the SW and NW plus exchanges from SW to NW.

3) From the NEPR to the Northeast Pacific. $30 \mathrm{Ma}$ ago, before the North American Plate overrode the mid-ocean ridge, there was probably a single biogeographic province in the eastern Pacific (Tunnicliffe 1988). The NEPR and the Northeast Pacific formed a continuous system of potential migration explaining the high similarities between these two regions (Tunnicliffe et al., 1998; Van Dover, 2000), which have 30 genera in common.

4) From the NEPR to the SEPR. Several barriers to dispersion have been invoked to explain the genetic differentiation between the NEPR and the SEPR, which have the largest number of taxa in common in our data (51 genera) and the strongest $D D$ coefficient. A dispersal filter was considered to be present around the equator, where the deep-oceanic currents and topographical features may limit faunal exchange between the NEPR and the SEPR by creating gyres. Phylogenetic studies (Hurtado et al., 2004) have led to the hypothesis of a biogeographic barrier at the level of the Easter Island Microplate south of the Equator, separating the $31^{\circ} \mathrm{S}$, Saguaro and German Flats fields from the other fields of our SEPR statistical province (Table 2). The MRT analysis identified these two subgroups, but we did not retain them as being separate in order to improve the robustness of the $D D$ analysis, because the southernmost group would only have contained three fields. A new biogeographic province may be recognized in this region when data become available from more fields of the Southeast Pacific below $30^{\circ} \mathrm{S}$.

As mentioned above, our results suggest that the East-Pacific Rise (NEPR and SEPR) may play a pivotal role as a centre of dispersal for the hydrothermal fauna. The NEPR had been suggested as a biogeographic or dispersal centre in previous studies because the species pool is very important in this oceanic zone (Van Dover and Hessler, 1990). In our data, NEPR also has the largest number of genera (151) consistent with its role as a centre of dispersal (see Material and Methods). Its high richness, however, may reflect the fact that it is one of the most intensely studied hydrothermal region. It has a high similarity with its neighbours: 51 genera are common with the SEPR, 30 with the Northeast Pacific, 25 with the Southwest Pacific, 19 with the MAR, and 15 with the Northwest Pacific. A total of sixty-nine genera are found exclusively in the NEPR. The number of genera in each statistical province is consistent with the hypothesis of dispersal and the geographic distribution of provinces: the SEPR is the nearest province to the NEPR and has the largest number of genera in common with it. On the other hand, the MAR has one of the lowest number of genera in common with the NEPR, probably because of the absence of direct historical connections between the Pacific and Atlantic ridges. Furthermore, the Pacific is the oldest ocean and the EPR was already active during the early Jurassic before the opening of Atlantic Ocean (Van Dover, 2000). Therefore, because the EPR is a fast-spreading ridge, hydrothermal activity is more frequent and variable than on a slow-spreading ridge and ecological succession tends to increase taxonomic diversity. Indeed, the study of Van Dover (1995) highlighted the consequences of fast- and slow-spreading rate on vent community succession. On slow ridges, communities are not frequently disturbed by tectonic activity, contrary to fast-spreading ridges. She highlighted the monotonic character of the MAR communities (slow-spreading ridge) contrary to the EPR (fast-spreading ridge), where communities change in numbers of individuals and increase in diversity with time. For example, the MAR communities have been shown to be dominated by the same taxa over decades, whereas the EPR has completely different dynamics (Van Dover, 2000). Second, according to Shank et al. (1998), microbial production is enhanced following magmatic eruptions, particularly because hydrogen sulfide and iron concentrations increase to very high values. In response to this increased microbial production, species like Riftia spp. or Tevnia spp. colonize the new vents formed after the eruption. The "pre-conditioning" of the habitat by these species allows other species to settle on vents. As a consequence, microbial production increases the number of invertebrate individuals and the "preconditioning" increases faunal diversity (Van Dover, 1995; Shank et al., 1998; Van Dover, 2000).

Our results are in agreement with the main continental plate-tectonic events as well as the position of Pacific Ridges and ocean history. The following problems must be considered, however. 
First, no faunal data are available for vast oceanic regions, in particular the South MAR, the northern portion of the North MAR, as well as the Arctic and the Antarctic oceans. These areas, and the backarcs basins, are the next exploration missions scheduled by ChEss (Chemosynthetic Ecosystem Science), a project of the Census of Marine Life programme. Second, the dispersal pathway between the NEPR and the MAR is not as evident as the other pathways for the following reasons. (1) No direct connection between the two ridges has been found. (2) The Caribbean plate may not have facilitated the exchanges between the NEPR and the MAR because of its isolation from the Cocos and the North American plates. It lost its connection to the Pacific with the formation of the Isthmus of Panama $3 \mathrm{Ma}$ ago. (3) Third, no genetic analyses were used in our study. They will be important to support our first results.

Complementary studies are required to support our conclusion about the importance of the EastPacific Rise (NEPR and SEPR) as a centre of dispersal for hydrothermal fauna. First, a phylogeographic study correlating historical geological events with the phylogeny of species belonging to some of the cosmopolitan hydrothermal groups, and examination of the reproduction and dispersal data about hydrothermal organisms, would allow us to understand the biological mechanisms underlying their dispersal among the provinces (Myers and Giller, 1988). Second, our model of hydrothermal dispersal could be extended to include data from cold seeps, which are another type of chemosynthetic ecosystem. Vents and seeps have several species, genera and families in common, suggesting that there are direct evolutionary links between them (Little and Vrijenhoek, 2003). Cold seeps may have played the role of stepping-stones in faunal exchanges, in particular between the NEPR and the MAR.

\section{Acknowledgments}

This research contributes to the project ChEss of Census of Marine Life and was supported by NSERC grant no. 7738 to P. Legendre and by ANR 06 BDIV 005 grant to D. Desbruyères.

\section{References}

ChEss, Biogeography of deep-water chemosynthetic ecosystems, for the census of marine life, ChEssBase Taxonomic Search, http://www.noc.soton.ac.uk/chess/database/.

Black, M.B., Halanych, K.M., Maas, P.A.Y., Hoeh, W.R., Hashimoto, J., Desbruyères, D., Lutz, R.A., Vrijenhoek, R.C. 1997. Molecular systematics of vestimentiferan tubeworms from hydrothermal vents and cold-water seeps. Marine Biology 130, 141-149.

Briggs, J.C. 1974. Marine Zoogeography, McGraw-Hill, New York.

Chevaldonné, P., Jollivet, D., Desbruyères, D., Lutz, R.A., Vrijenhoek, R. C., 2002. Sister-species of eastern Pacific hydrothermal vent worms (Ampharetidae, Alvinellidae, Vestimentifera) provide new mitochondrial COI clock calibration. Cahiers de Biologie Marine 43(3-4), 367-370.

De'ath, G., 2002. Multivariate regression trees: a new technique for constrained classification analysis. Ecology 83, 1105-1117.

De'ath, G., 2006. mvpart: multivariate partitioning. R package version 1.2-4. http://cran.r-project.org/. Desbruyères, D., Segonzac, M., Bright, M., 2006. Handbook of Deep-Sea Hydrothermal Vent Fauna. Denisia 18, Linz-Dornach.

Gebruk, A.V., Galkin, S.V., Vereshchaka, A.L., Moskalev, L.I., Southward, A.J., 1997. Ecology and biogeography of the hydrothermal vent fauna of the Mid-Atlantic Ridge. Advances in Marine Biology 32, 93-144.

German, C.R., Bennett, S.A., Connelly, D.P, Evans, A.J., Murton, B.J., Parson, L.M., Prien, R.D. Ramirez-Llodra, E., Jakuba, M., Shank, T.M., Yoerger, D.R, Baker, E.T., Walker, S.L., Nakamura, N. (in press). Hydrothermal activity on the southern Mid-Atlantic Ridge: Tectonically- and volcanicallycontrolled venting at $4-5^{\circ} \mathrm{S}$. Earth and Planetary Science Letters. 
Hedges, S.B., Parker, P.H., Sibley, C.G., Kumar, S. 1996. Continental breakup and the ordinal diversification of birds and mammals. Nature 381, 226-229.

Hessler, R.R., Lonsdale, P.F., 1991. Biogeography of Mariana Trough hydrothermal vent communities. Deep Sea Research Part A 38, 185-199.

Holm, S., 1979. A simple sequentially rejective multiple test procedure. Scandinavian Journal of Statistics 6, 65-70.

Hurtado, L.A. (2002). Evolution and biogeography of hydrothermal vent organisms in the Eastern Pacific Ocean. Ph.D. Thesis, Rutgers University, New Brunswick, NJ.

Hurtado, L.A., Lutz, R.A., Vrijenhoek, R.C., 2004. Distinct patterns of genetic differentiation among annelids of eastern Pacific hydrothermal vents. Molecular Ecology 13, 2603-2615.

Jacobs, D.K., Lindberg, D.R. 1998. Oxygen and evolutionary patterns in the sea: onshore/offshore trends and recent recruitment of deep-sea faunas. Proceedings of the National Academy of Sciences of the USA 95, 9396-9401.

James K.H. 2004. A simple synthesis of Caribbean geology. Adapted from "extended abstract" for presentation at the AAPG International Conference, Barcelona, Spain, September 21-24, 2003.

Jollivet, D. (1996). Specific and genetic diversity at deep-sea hydrothermal vents: an overview. Biodiversity and Conservation 5, 1619-1653.

Jollivet, D., Comtet, T., Chevaldonné, P., Hourdez, S., Desbruyères, D., Dixon D.R., 1998. Unexpected relationship between dispersal strategies and speciation within the association Bathymodiolus (Bivalvia) - Branchipolynoe (Polychaeta) inferred from the dDRA neutral ITS2 marker. Cahiers de Biologie Marine 39, 359-362.

Kiel, S., Little, C.T.S. 2006. Cold-seep mollusks are older than the general marine mollusk fauna. Science 313, 1429-1431.

Legendre, P., Legendre, V., 1984. Postglacial dispersal of freshwater fishes in the Québec peninsula. Canadian Journal of Fisheries and Aquatic Sciences 41, 1781-1802.

Legendre, P., Legendre, L., 1998. Numerical Ecology, Elsevier Scientific Publishing Company, Amsterdam.

Legendre, P., Gallagher, E.D., 2001. Ecologically meaningful transformations for ordination of species data. Oecologia 129, 271-280.

Little, C.T.S., Vrijenhoek, R.C., 2003. Are hydrothermal vent animals living fossils? Trends in Ecology and Evolution 18, 562-588.

McArthur, A.G., Tunnicliffe ,V. 1998. Relics and antiquity revisited in the modern vent fauna. In

Modern Ocean Floor Processes and the Geological Record, R. A. Mills and K. Harrison, eds. Geological Society, London.

Mironov, A.N., Gebruk, A.V., Mosjalev, L.I., 1998. Biogeography patterns of the hydrothermal vent fields: a comparison with non-vent biogeography. Cahiers de Biologie Marine 39, 367-368.

Myers, A.A., Giller, P.S., 1988. Process, pattern and scale in biogeography. In Analytical Biogeography, Chapman and Hall, London.

Nelson, G., Platnick, N., 1981. Systematics and Biogeography: Cladistics and Vicariance, Columbia University Press, New York.

New Millennium Observatory (NeMO): a seafloor observatory at an active underwater volcano. NeMO Expeditionsfile, http://www.pmel.noaa.gov/vents/nemo/ (2006).

NOAA, National Oceanic and Atmospheric Administration, PMEL, Pacific Marine Environmental Laboratory, Vents Program, researching the effects of underwater hydrothermal venting systems. http://www.pmel.noaa.gov/ (2006).

Oksanen, J. Kindt R., Legendre P., O'Hara R.B., 2008. vegan: community ecology package. R package version 1.11-0. http://cran.r-project.org/, http://vegan.r-forge.r-project.org/.

R Development Core Team, 2006. R: A language and environment for statistical computing. $R$ Foundation for Statistical Computing, Vienna, Austria.

Rosenzweig, M.L., 1995. Species Diversity in Space and Time. Cambridge University Press, Cambridge, Great Britain. 
Shank T.M., Fornari D.J., Von Damm K.L., Lilley M.D., Haymon R.M., Lutz R.A., 1998. Temporal and spatial patterns of biological community development at nascent deep-sea hydrothermal vents. Deep Sea Research II 45: 465-516.

Tsurumi, M., Tunnicliffe, V. (2003). Tubeworm-associated communities at hydrothermal vents on the Juan de Fuca Ridge, northeast Pacific. Deep Sea Research I 50, 611-629.

Tunnicliffe, V., 1991. The biology of hydrothermal vents: ecology and evolution. Oceanography and Marine Biology An Annual Review 29, 319-407.

Tunnicliffe, V., 1997. Hydrothermal vents: a global system. In JAMSTEC Technical Reports "Deep Sea Research in subduction zones, spreading centers and back arc basins", 105-114.

Tunnicliffe, V., Desbruyères, D., McArthur, A.G., 1996. Plate tectonic history and hot vent biogeography. In Tectonic, Magmatic, Hydrothermal and Biological Segmentation of Mid-Oceans Ridges. Geological Society, London, Special Publications 118, 225-238.

Tunnicliffe, V., McArthur, G.A., McHugh, D., 1998. A biogeographical perspective of the deep-sea hydrothermal vent fauna. Advances in Marine Biology 34, 355-442.

Tyler, P.A., Young, C.M.Y. 1999. Reproduction and dispersal at vents and cold seeps. Journal of the Marine Biological Association of the United Kingdom 79, 193-208.

Tyler, P.A., Young, C.M.Y. 2003. Dispersal at hydrothermal vents: a summary of recent progress. Hydrobiologia 503(1-3), 9-19.

Van Dover, C.L., Hessler, R.R., 1990. Spatial variation in faunal composition of hydrothermal vent communities on the East Pacific Rise and Galapagos Rift. In Gorda Ridge: A Seafloor Spreading Center in the United States Exclusive Economic Zone. Springer-Verlag, New-York.

Van Dover, C.L., 1995. Ecology of Mid-Atlantic Ridge hydrothermal vents. Geological Society, London, Special Publications 87: 257-294.

Van Dover, C.L., 2000. The Ecology of Deep-Sea Hydrothermal Vents, Princeton University Press, Princeton.

Van Dover, C.L., Humphris, S.E., Fornari, D., Cavanaugh, C.M., Collier, R., Goffredi, S.K., Hashimoto, J., Lilley, M.D., Reysenbach, A.L., Shank, T.M., Von Damm, K.L., Banta, A., Gallant, R.M., Götz, D., Green, D., Hall, J., Harmer, T.L., Hurtado, L.A., Johnson, P., McKiness, Z.P., Meredith, C., Olson, C., Pan, I.L., Turnipseed, M., Won, Y., Young, C.R., Vrijenhoek, R.C., 2001. Biogeography and ecological setting of Indian Ocean hydrothermal vents. Science 294, 818-823.

Van Dover, C.L., German, C.R., Speer, K.G., Parson, L.M., Vrijenhoek, R.C., 2002. Evolution and Biogeography of deep-sea vent and seep invertebrates. Science 295(5558), 1253-1257. 


\section{Tables}

Appendix. Supplementary data.

Supplementary Table 1 (attached file, "Annexe".

\section{Appendix 2}

Names of the 63 vent fields, abbreviations, localizations on the ridges, geographic coordinates (degrees and minutes), decimal coordinates (used in the analyses), and identification numbers on the maps. 


\begin{tabular}{|c|c|c|c|c|c|c|}
\hline $\begin{array}{c}\text { Field } \\
\text { (abbreviation) }\end{array}$ & Ridge & $\begin{array}{l}\text { Latitude } \\
\text { deg-min }\end{array}$ & $\begin{array}{l}\text { Longitude } \\
\text { deg-min }\end{array}$ & $\begin{array}{c}\text { Latitude } \\
\text { decimal deg }\end{array}$ & $\begin{array}{c}\text { Longitude } \\
\text { decimal deg }\end{array}$ & $\begin{array}{c}\text { Field number } \\
\text { on map }\end{array}$ \\
\hline Kagoshima Bay (KB) & Japan Ridge & $31^{\circ} 39 \mathrm{~N}$ & $130^{\circ} 48 \mathrm{E}$ & 31.65000 & 130.80000 & 3 \\
\hline Hatoma Knoll (HK) & Okinawa Trough & $28^{\circ} 24 N$ & $123^{\circ} 50 \mathrm{E}$ & 28.40000 & 123.83333 & 4 \\
\hline $\begin{array}{l}\text { North Iheya Knoll } \\
\text { (NIK) }\end{array}$ & Okinawa Trough & $27^{\circ} 47 \mathrm{~N}$ & $126^{\circ} 54 \mathrm{E}$ & 27.78333 & 126.90000 & 6 \\
\hline Iheya Ridge (IR) & Okinawa Trough & $27^{\circ} 33 \mathrm{~N}$ & $126^{\circ} 59 \mathrm{E}$ & 27.55000 & 126.98333 & 7 \\
\hline Izena Cauldron (IC) & Okinawa Trough & $27^{\circ} 16 \mathrm{~N}$ & $127^{\circ} 05 \mathrm{E}$ & 27.26667 & 127.08333 & 8 \\
\hline $\begin{array}{l}\text { Northeastern Taiwan } \\
\text { (NET) }\end{array}$ & Okinawa Arc & $24^{\circ} 50 \mathrm{~N}$ & $121^{\circ} 60 \mathrm{E}$ & 24.83333 & 122.00000 & 9 \\
\hline Suiyo Seamount (SS) & $\begin{array}{l}\text { Izu-Ogasawara } \\
\text { Arc }\end{array}$ & $28^{\circ} 34 \mathrm{~N}$ & $140^{\circ} 39 \mathrm{E}$ & 28.56667 & 140.65000 & 12 \\
\hline Sumisu Caldera (SC) & $\begin{array}{c}\text { Izu-Ogasawara } \\
\text { Arc }\end{array}$ & $31^{\circ} 28 \mathrm{~N}$ & $140^{\circ} 04 \mathrm{E}$ & 31.46667 & 140.06667 & 13 \\
\hline $\begin{array}{ll}\begin{array}{l}\text { Kaikata } \\
(\mathrm{KS})\end{array} & \text { Seamount } \\
\end{array}$ & $\begin{array}{l}\text { Izu-Ogasawara } \\
\text { Arc }\end{array}$ & $26^{\circ} 42 \mathrm{~N}$ & $141^{\circ} 04 \mathrm{E}$ & 26.70000 & 141.06667 & 14 \\
\hline Nikko Seamount (NS) & $\begin{array}{c}\text { Izu-Ogasawara } \\
\text { Arc }\end{array}$ & $23^{\circ} 06 \mathrm{~N}$ & $142^{\circ} 40 \mathrm{E}$ & 23.10000 & 142.66667 & 15 \\
\hline Mariana Trough (MT) & $\begin{array}{l}\text { Mariana Back-Arc } \\
\text { Basin }\end{array}$ & $18^{\circ} 12 \mathrm{~N}$ & $144^{\circ} 42 \mathrm{E}$ & 18.20000 & 144.70000 & 16 \\
\hline $\begin{array}{ll}\begin{array}{l}\text { Edison } \\
\text { (EDS) }\end{array} & \text { Seamount } \\
\end{array}$ & $\begin{array}{c}\text { Tabar-Feni } \\
\text { Volcanic Fore Arc }\end{array}$ & $03^{\circ} 01 \mathrm{~S}$ & $152^{\circ} 03 \mathrm{E}$ & -3.01667 & 152.05000 & 17 \\
\hline Vienna Woods (VW) & $\begin{array}{c}\text { Manus Back-Arc } \\
\text { Basin }\end{array}$ & $03^{\circ} 09 \mathrm{~S}$ & $150^{\circ} 16 \mathrm{E}$ & -3.15000 & 150.26667 & 18 \\
\hline
\end{tabular}




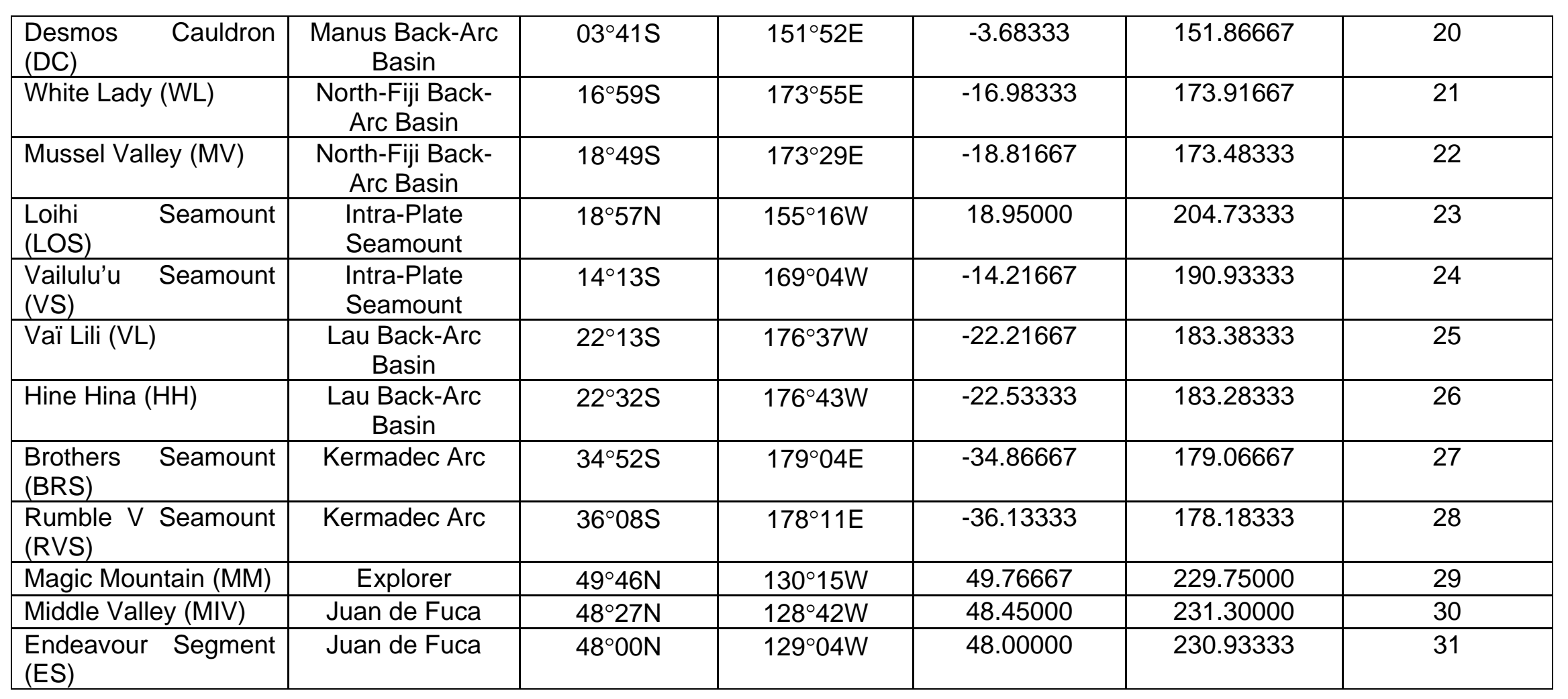




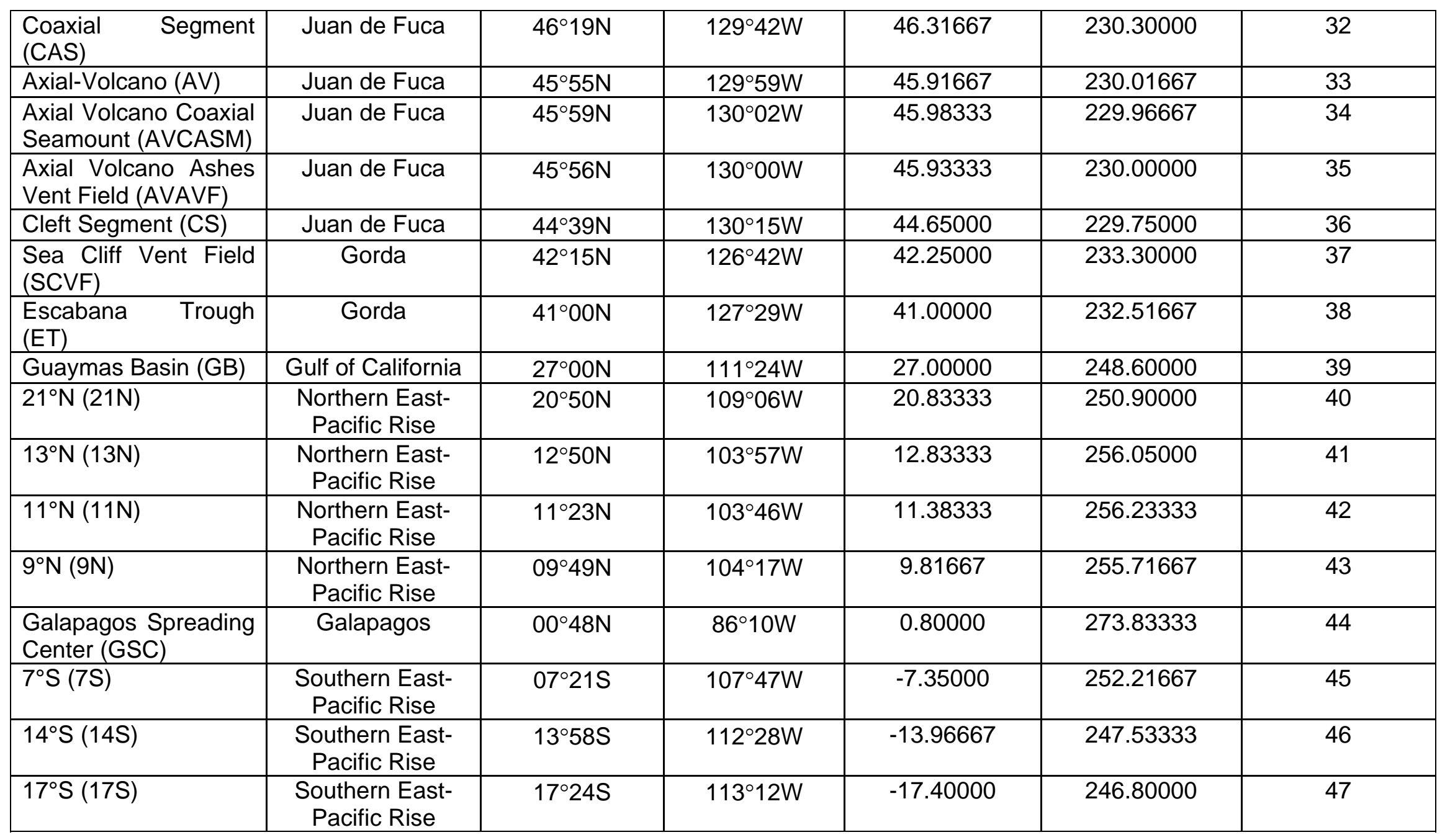




\begin{tabular}{|c|c|c|c|c|c|c|}
\hline $17^{\circ} 24 S(1724 S)$ & $\begin{array}{l}\text { Southern East- } \\
\text { Pacific Rise }\end{array}$ & $17^{\circ} 25 \mathrm{~S}$ & $113^{\circ} 12 \mathrm{~W}$ & -17.40000 & 246.80000 & 48 \\
\hline $21^{\circ} \mathrm{S}(21 \mathrm{~S})$ & $\begin{array}{l}\text { Southern East- } \\
\text { Pacific Rise }\end{array}$ & $21^{\circ} 25 S$ & $114^{\circ} 17 \mathrm{~W}$ & -21.41667 & 245.71667 & 51 \\
\hline $23^{\circ} \mathrm{S}(23 \mathrm{~S})$ & $\begin{array}{l}\text { Southern East- } \\
\text { Pacific Rise }\end{array}$ & $23^{\circ} 32 S$ & $115^{\circ} 34 \mathrm{~W}$ & -23.53333 & 244.43333 & 52 \\
\hline $31^{\circ} \mathrm{S}(31 \mathrm{~S})$ & $\begin{array}{l}\text { Southern East- } \\
\text { Pacific Rise }\end{array}$ & $31^{\circ} 09 S$ & $111^{\circ} 55 \mathrm{~W}$ & -31.15000 & 248.08333 & 53 \\
\hline Saguaro Field (SF) & $\begin{array}{l}\text { Southern East- } \\
\text { Pacific Rise }\end{array}$ & $31^{\circ} 51 S$ & $112^{\circ} 02 \mathrm{~W}$ & -31.85000 & 247.96667 & 54 \\
\hline German Flats (GF) & $\begin{array}{l}\text { Southern East- } \\
\text { Pacific Rise }\end{array}$ & $37^{\circ} 47 \mathrm{~S}$ & $110^{\circ} 55 \mathrm{~W}$ & -37.78333 & 249.08333 & 55 \\
\hline Menez Gwen (MG) & $\begin{array}{l}\text { Mid-Atlantic } \\
\text { Ridge }\end{array}$ & $37^{\circ} 51 \mathrm{~N}$ & $31^{\circ} 31 \mathrm{~W}$ & 37.85000 & 328.48333 & 56 \\
\hline Broken Spur (BS) & $\begin{array}{l}\text { Mid-Atlantic } \\
\text { Ridge }\end{array}$ & $29^{\circ} 10 \mathrm{~N}$ & $43^{\circ} 10 \mathrm{~W}$ & 29.16667 & 316.83333 & 59 \\
\hline TAG (TAG) & $\begin{array}{l}\text { Mid-Atlantic } \\
\text { Ridge }\end{array}$ & $26^{\circ} 08 \mathrm{~N}$ & $44^{\circ} 49 \mathrm{~W}$ & 26.13333 & 315.18333 & 60 \\
\hline Snake Pit (SP) & $\begin{array}{l}\text { Mid-Atlantic } \\
\text { Ridge }\end{array}$ & $23^{\circ} 23 \mathrm{~N}$ & $44^{\circ} 58 \mathrm{~W}$ & 23.38333 & 315.03333 & 61 \\
\hline Logatchev (Log) & $\begin{array}{l}\text { Mid-Atlantic } \\
\text { Ridge }\end{array}$ & $14^{\circ} 45 \mathrm{~N}$ & $44^{\circ} 58 \mathrm{~W}$ & 14.75000 & 315.03333 & 62 \\
\hline Ashadze 1 (A1) & $\begin{array}{l}\text { Mid-Atlantic } \\
\text { Ridge }\end{array}$ & $12^{\circ} 58 \mathrm{~N}$ & $44^{\circ} 52 \mathrm{~W}$ & 12.96667 & 315.13333 & 63 \\
\hline
\end{tabular}




\section{Figures}

Fig. 1. Geographic distribution of the 63 hydrothermal fields studied in a model with 6 biogeographic provinces. The complete name of each field, their location on the ridges, back-arc basins, submarine volcanoes and the abbreviations used during the analyses are shown in the Supplementary Tables 1 and 2. The envelopes represent the 6-province biogeographic model. The arrows indicate the significant coefficients of dispersal direction (values of $D D_{2}$ on the arrows, underscored). 


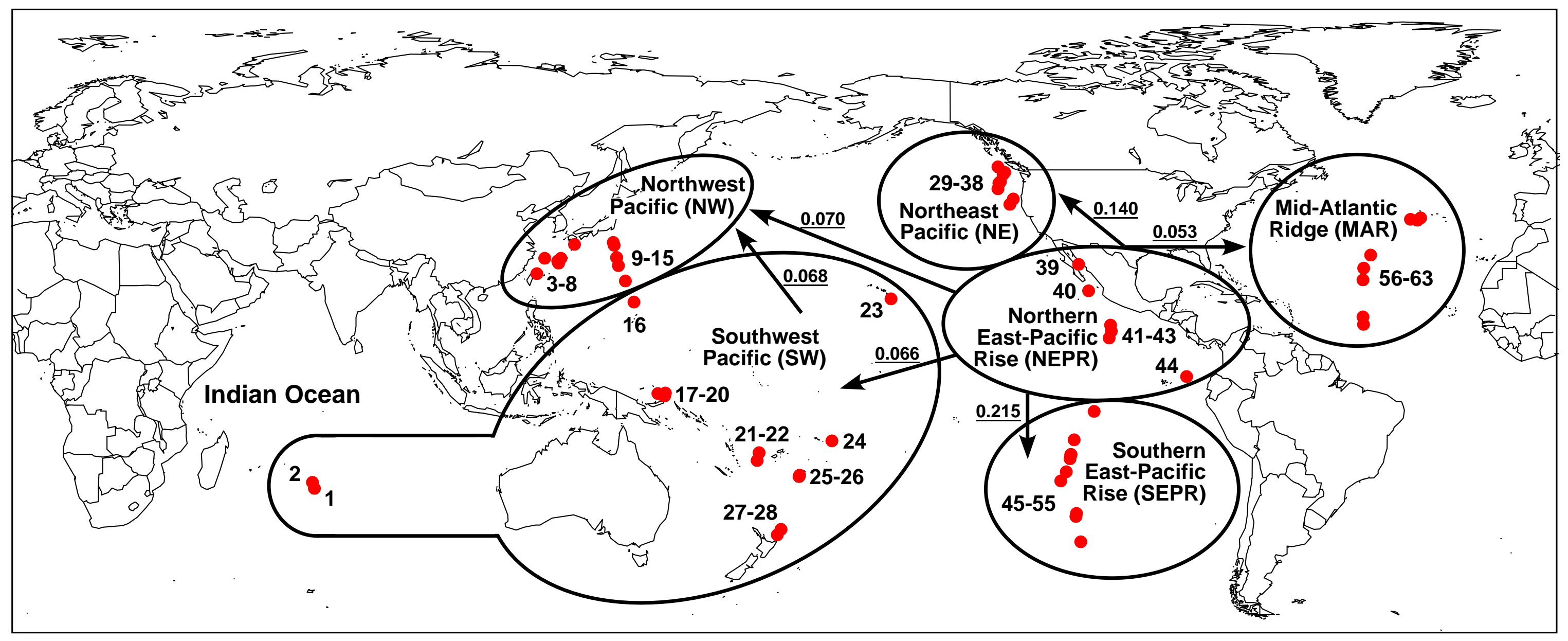


Fig. 2. Six-province model obtained by multivariate regression tree (MRT) analysis of the community composition data, using latitude and longitude as the constraining variables. $n$ is the number of fields in each statistical province. Latitudes are from the equator, longitudes are east from Greenwich. The fields forming each province are represented by numbers (Table 2). The tree was redrawn as a function of the explanatory power of the groups ( $R^{2}$ values in ordinate) as the number of groups increases from 2 to 6. 


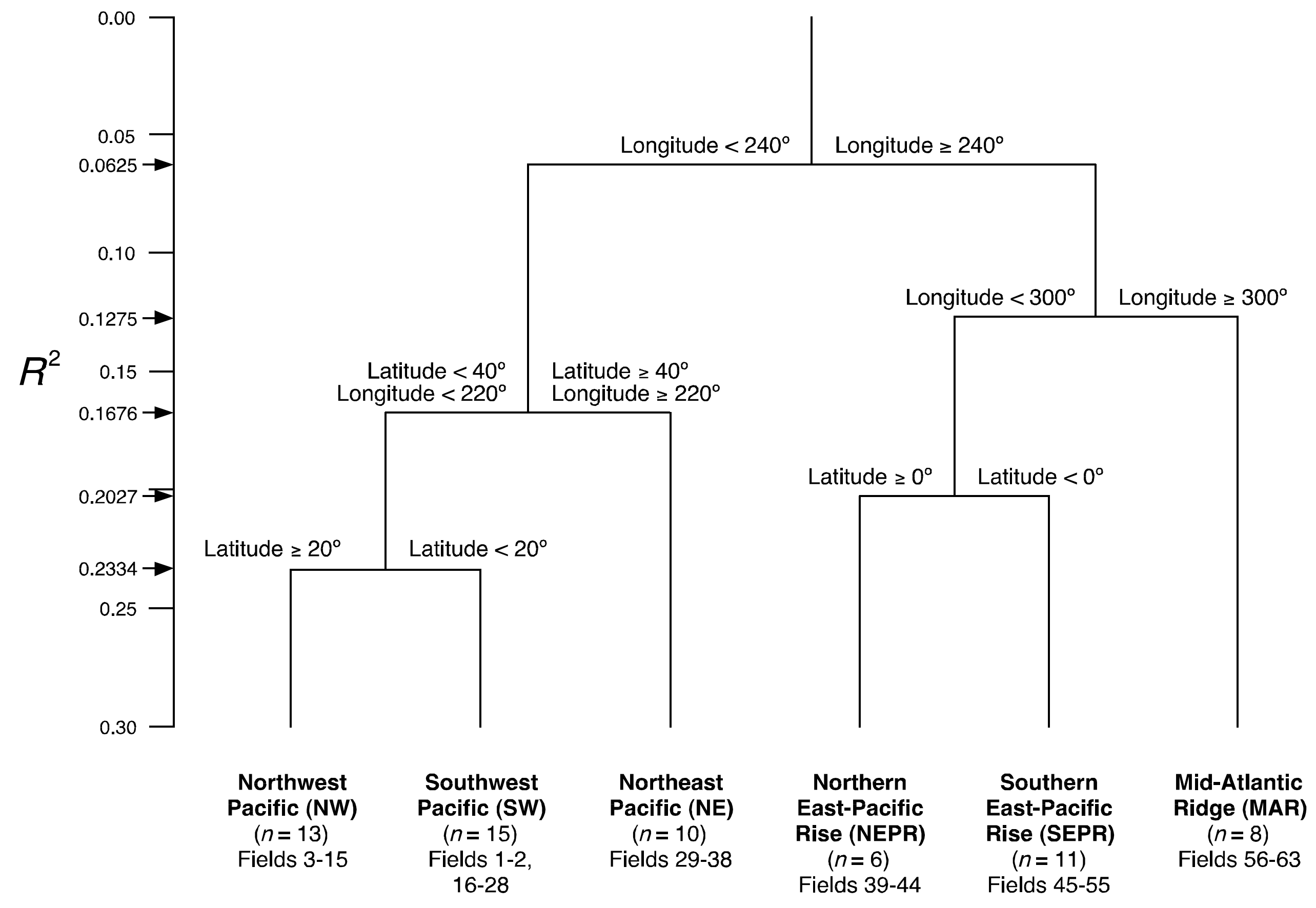


Fig. 3. Full lines: minimum spanning tree (MST) computed from the Sørensen similarity coefficients among provinces. The Sørensen similarity values are shown on the lines. Arrowheads added when MST links are also significant $D D_{2}$ coefficients. Gray dashed arrows: the two $D D_{2}$ coefficients from Fig. 1 that are not also MST links. 


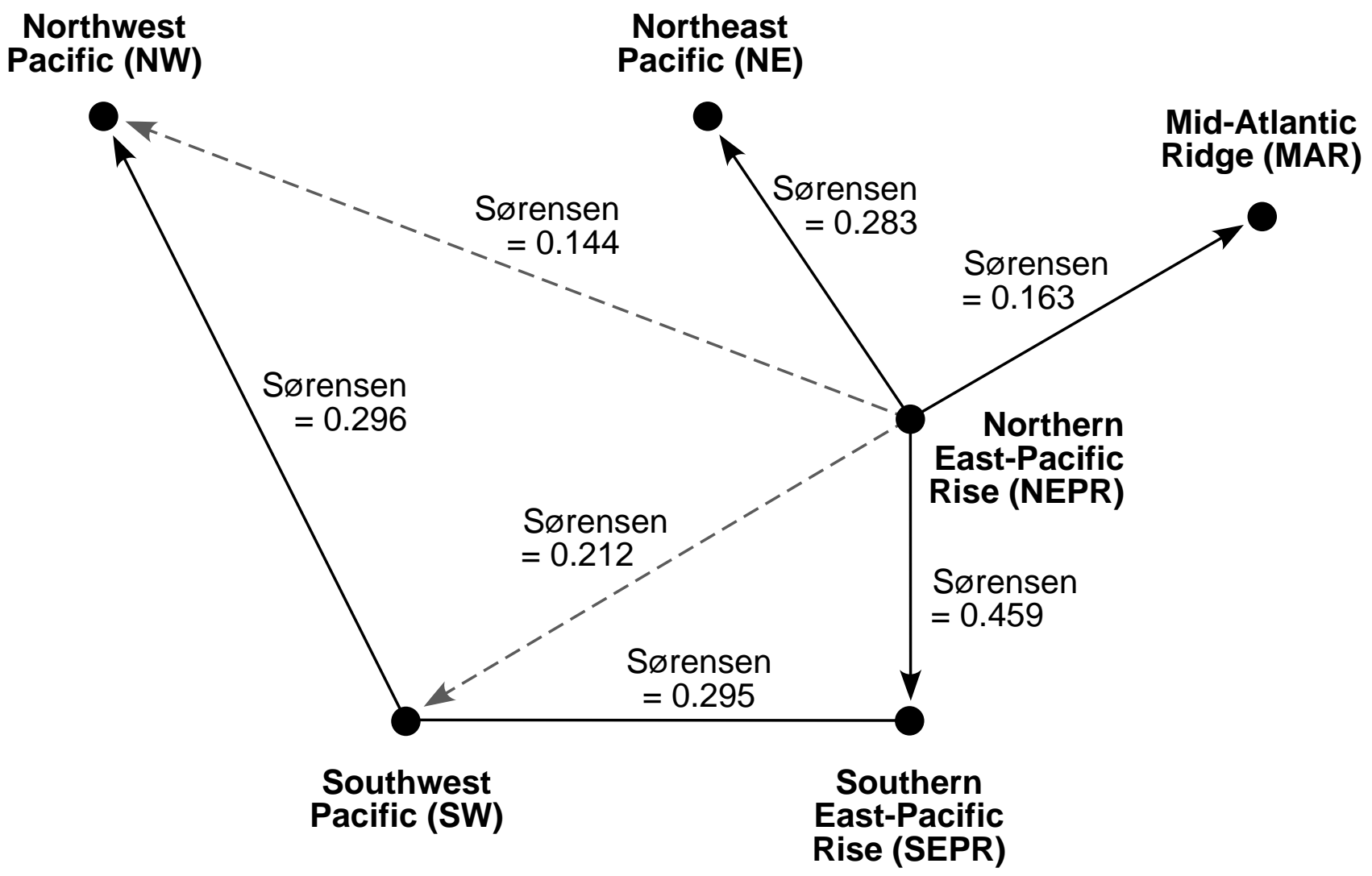

